\title{
Evidence for Holocene Aeolian Activity at the Close of the Middle Bronze Age in the Eastern Carpathian Basin: Geoarchaeological Results from the Mureş River Valley, Romania
}

\author{
Sarah C. Sherwood, ${ }^{1, *}$ Jason D. Windingstad, ${ }^{2}$ Alex W. Barker, ${ }^{3}$ John M. O'Shea, ${ }^{4}$ and W. Cullen Sherwood ${ }^{5}$ \\ ${ }^{1}$ Environmental Studies, University of the South, Sewanee, Tennessee \\ ${ }^{2}$ Statistical Research, Inc., Tucson, Arizona \\ ${ }^{3}$ Museum of Art \& Archaeology, University of Missouri, Columbia, Missouri \\ ${ }^{4}$ Museum of Anthropology, University of Michigan, Ann Arbor, Michigan \\ ${ }^{5}$ Department of Geology and Environmental Science, James Madison University, Harrisonburg, Virginia
}

\begin{abstract}
Correspondence
*Corresponding author;

E-mail: sherwood@sewanee.edu

Received

29 July 2012

Accepted

9 December 2012

Scientific editing by Jamie Woodward

Published online in Wiley Online Library (wileyonlinelibrary.com).
\end{abstract}

doi 10.1002/gea.21434

\begin{abstract}
While extensive Pleistocene loess deposits have been identified across Eurasia, Holocene age loess (typically nonglaciogenic) is rarely recognized. We explore possible loess deposits in the Mureş River Valley of western Romania, providing a regional signal of increased aridity during the mid-late Holocene. This proposed aridity may be responsible for the abandonment of Middle Bronze Age tell settlements along the major drainages of the eastern Carpathian Basin (Pannonian plain). This hypothesis centers on a proposed aeolian deposit (the "Pecica deposit"), a ca. 50-80 cm thick, relatively homogeneous, gray layer blanketing the top of the Bronze Age tell of Pecica-Şanţul Mare. Comparing the morphological, geochemical, and physical characteristics of this specific tell deposit with two representative profiles near the site containing glaciogenic calcareous loess and potential Holocene loess deposits developed in Chernozems, we find significant similarities to support this hypothesis. We then review various forms of proxy data published from elsewhere in Central and Eastern Europe suggesting a warming trend during this period. The temporal placement of the Pecica deposit is bracketed using diagnostic artifacts, radiocarbon dates, and the degree of soil development, suggesting a period of increased aridity likely occurring soon after the 17th century B.C. (C) 2013 Wiley Periodicals, Inc.
\end{abstract}

\section{INTRODUCTION}

Beginning around 2500 B.C., a series of large tell settlements appear along the major drainages of the eastern Carpathian Basin (Pannonian plain) (Tasić, 1984; Bogdanović, 1996; Gumä, 1997; Draşovean, 1999; Harding, 2000; Gogâltan, 2008). The inhabitants managed a broad spectrum subsistence economy that incorporated both wild and domestic plants and animals, and participated in a dynamic trade network linked to rich ore deposits in the Transylvanian Mountains to the east. The communities producing these tells began as middlerange societies with some evidence for incipient ranking (O'Shea, 1996). The tell settlements persisted for nearly a millennium and then were abruptly abandoned. Although many causes for the abandonment have been suggested, the absence of a firm absolute chronology for the region has precluded definitive resolution to the question. Radiocarbon dates and geoarchaeological analyses (the first for the region) associated with the recent tell excavations at Pecica-Şanţul Mare, on the Mureş River in western Romania (O'Shea et al., 2005, 2006, 2011) allow a new hypothesis to be put forth based on the discovery of a deposit(s) suggestive of a period of increased aeolian deposition that may indicate aridity that likely occurred soon after the 17th century cal. B.C. This proposed mid-late Holocene deposition, herein referred to as the "Pecica deposit", may have significant implications for the abandonment of Middle Bronze Age (MBA) tells in the Eastern Carpathian Basin, and in the subsequent distribution of sites across the Pannonian plain. This proposed aeolian deposit may also explain the supposed 
absence of pre-Iron Age sites in various localities, especially to the north and west into the Pannonian plain (Gyucha, Duffy, \& Frolking, 2011). Older sites could instead be buried in the areas of significant Holocene aeolian deposition and may go undetected with traditional survey techniques.

The hypothesis presented here had its beginnings in the recording of the local environmental setting of the Bronze Age tell at Pecica-Şanţul Mare, when we documented an approximately 50-80 cm thick, relatively homogeneous, gray deposit blanketing the top of the tell and the surrounding area. In past excavations and site visits, the massive gray deposit was assumed to be the result of a significant burning episode, perhaps occurring during the initial Dacio-Roman occupation of the tell. These deposits, however, have been observed and recorded over a $6 \mathrm{~km}$ radius of the site. A similar deposit has also been recorded by O'Shea immediately above the MBA occupation layers at the Hungarian site of KlárafalvaHajdova located down valley ca. $50 \mathrm{~km}$ and is predicted to extend further, up and down the Mureş River Valley. The tell site of Klárafalva-Hajdova was also abandoned around the end of the 17th century B.C. (O'Shea, 1992).

We propose the Pecica deposit is a Holocene aeolian layer, perhaps signaling a period of aridification that had a direct impact on the termination of significant regional MBA activity in the area. While extensive Pleistocene loess deposits have been identified across Eurasia (e.g., Rost, 2001; Chengbang, Zhaudong, \& Tang, 2004), Holocene age loess (typically nonglaciogenic) is rarely recognized in this part of the world. This lack may be surprising in view of its potential to record terrestrial responses to regional and continental-scale climate change, which can in turn provide insights into prehistoric landuse practices and human responses to climatic shifts. Such fine-scale climatic signatures may be especially significant in Eurasia, where climato-stratigraphic data rooted in absolute Holocene chronologies are scarce (see Finné et al., 2011). Please note that we use the terms aeolian and loess interchangeably in this paper although loess is often restricted to direct glacial origins.

In this paper, we attempt to correlate the Pecica deposit with two regionally representative loess soil profiles. We compare the morphological, geochemical, and physical characteristics of this specific deposit with glaciogenic calcareous loess and potential Holocene loess deposits identified during this study along the Mureş River and the Pleistocene tableland terrace where the site of Pecica-Şanţul Mare, is located. We also explore the possibility of the Pecica deposit, at least on the tell itself, being anthropogenic in origin. To temporally place the Pecica deposit, we rely on radiocarbon dates recently published from the tell site and an assessment of the degree of soil development observed.

\section{SETTING AND BACKGROUND}

Today the climate in the Eastern Carpathian Basin is considered continental with warm summers and moderate winters. The average temperature is $10.5^{\circ} \mathrm{C}$ with $\sim 550 \mathrm{~mm}$ average rainfall (Sandu, 2011). The Mureş River is an important tributary in the eastern Danube catchment with a $30,000 \mathrm{~km}^{2}$ drainage basin (Andó, 1995:7). The river drains the western Carpathians and Apuseni Mountains flowing in a westerly direction, joining the Tisza River at Szeged, Hungary, which then flows south to the Danube (Figure 1). During the Bronze Age, this area of Eastern Europe would have been under the Atlantic climatic influence. This period was a time of general cooling with large areas of deciduous forests transitioning into parkland and steppe. Today the lower reaches of the Mureş River in Romania are entrenched, creating a steep sided valley ( $\sim 20 \mathrm{~m}$ deep, $1-3 \mathrm{~km}$ wide) passing through the eastern edge of the Pannonian plain (Figure 2). Here, the plain is composed of a sequence of Pleistocene alluvial terraces containing a series of thick fluvial-loess soils. The terraces developed downstream from the relatively steep palaeo-Mureş alluvial fan complex that formed as the river deposited coarse sediments from the Apuseni Mountains depending on the direction and degree of differential uplift and subsidence from the complicated tectonic evolution that exerted strong control over the development of the Pannonian Basin river patterns (Nádor et al., 2007:175; Kiss et al., 2011).

While sections of the Mureş(Maros) floodplain were altered through Romania and Hungary in the early 19th century, remnants of natural levees, complex relic meander patterns, and historic flood data serve as evidence for the dynamic hydrologic history of the floodplain. Today the regional floodplain, designated the "Mureş Floodplain Natural Park," includes wetlands, and riparian zones covered with oaks, ash, elm, poplar, and willow, and is considered to be among the last quasi-natural or natural forest wetland habitats in the European temperate region (Pîrv \& Pascu, 2006). The river floods at least twice a year currently and carries significant sediment loads resulting in overbank deposition. The bedload average median grain size is $0.2-0.3 \mathrm{~mm}$, while that of the suspended load is 0.04-0.05 mm (Kiss et al., 2011:192).

Most of southeastern Europe is blanketed in loess, originally created by the settling of predominantly siltsize sediments (typically quartz but also calcium carbonate and feldspars depending on the source), raised and conveyed by winds in the wake of significant erosion 


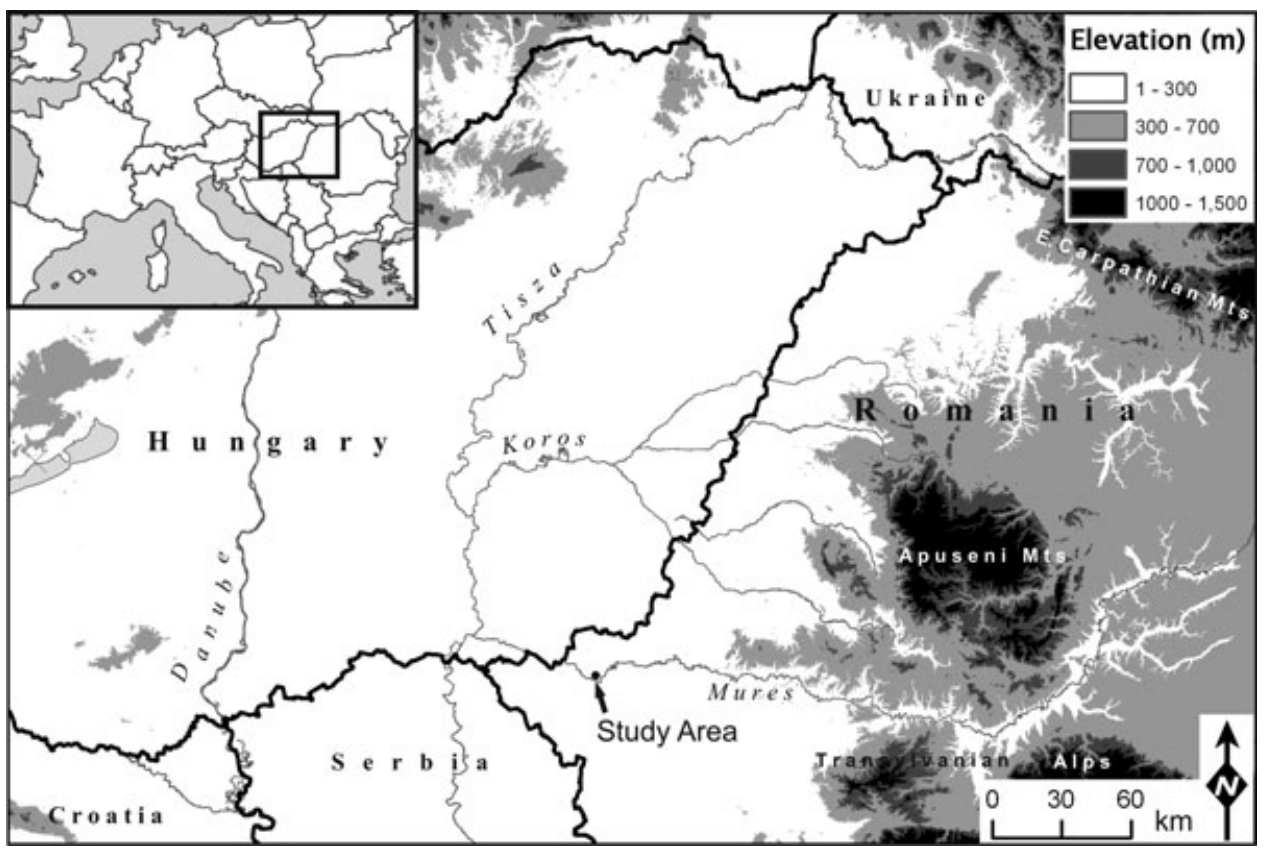

Figure 1 Map of the Eastern Carpathian Basin (Pannonian plain) emphasizing the Mureş River Valley and the location of the study area.

ultimately caused by climatic conditions (Pécsi, 1990; Smalley, 1995). According to Pye (1995:653), for loess to form there must be: (1) a sustained source of fine clastic sediment, (2) adequate wind energy to transport it, and (3) a suitable accumulation site. During the Pleistocene, the source resulted from glacial activity, but during the Holocene the sediment available was typically due to some combination of increased aridity and/or

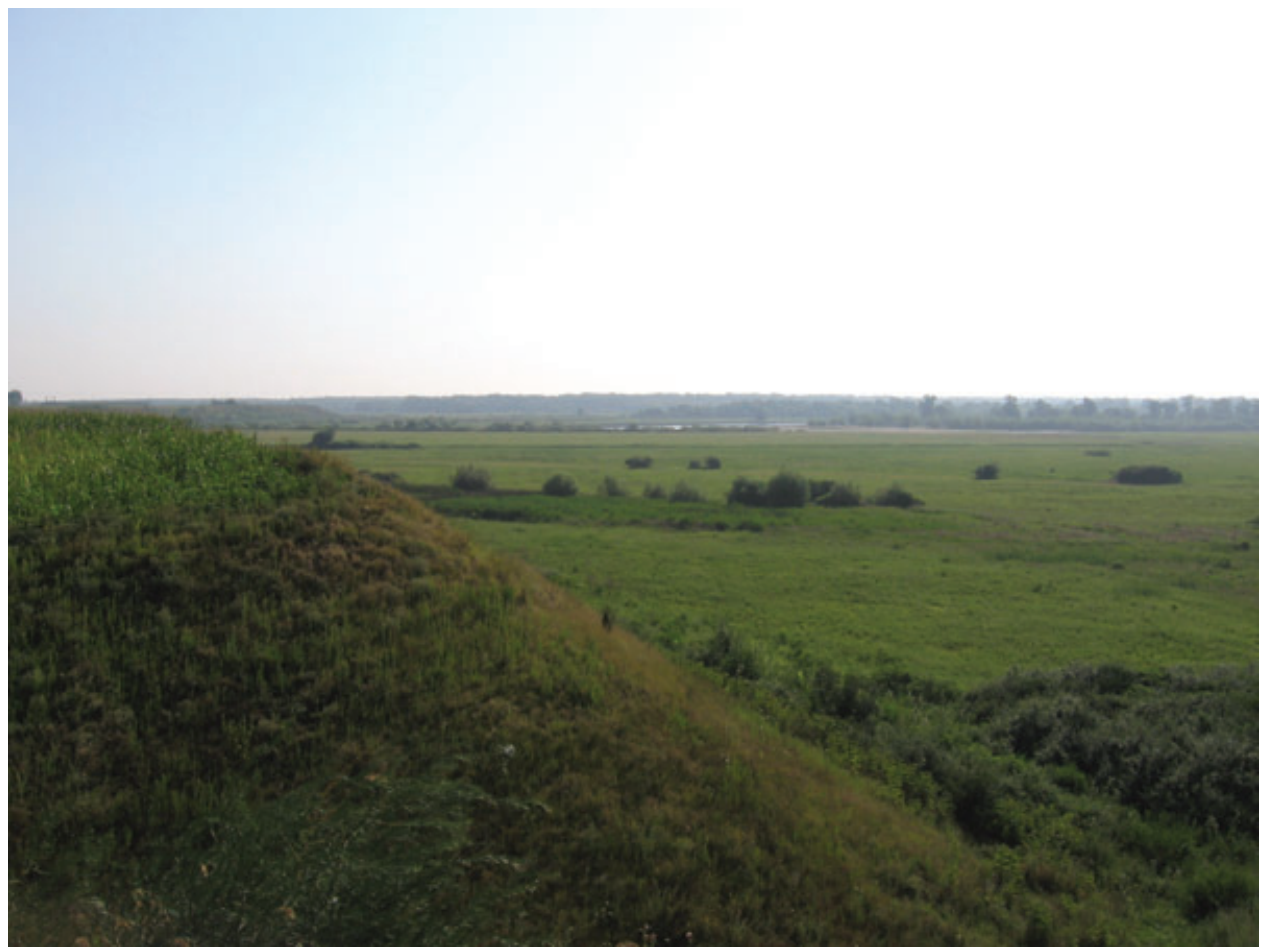

Figure 2 View looking east up the Mureş River Valley near the site of Pecica_Şanţul Mare showing the steep edge of the loess plateau and the floodplain. 
significant flood deposition, deforestation, and anthropogenic ground disturbance from agricultural expansion. The Pannonian plain has the highest concentration of loess and the thickest and most complete loess profiles in Europe (Hasse et al., 2007; Marković et al., 2011), yet they are the least understood (Fitzsimmons, Marković, $\delta$ Hambach, 2012:105).

The soils of the Pannonian plain are mapped primarily as calcareous Chernozems and are extensively cultivated (Florea et al., 1978). Chernozems are steppe soils characterized by the accumulation of humus under a semiarid continental climate with tall-grass vegetation that provides a relatively high, below-ground biomass (Driessen et al., 2001). Chernozems commonly form in calcareous parent materials (typically loess) and bioturbation is usually considered a prerequisite for their development. Chernozem research in Eastern Europe suggests that the genesis and distribution of these soils is related to climatic variability and deforestation in the early Holocene with their formation taking place prior to the early Neolithic Period (5500-5000 B.C.) (Eckmeier et al., 2007). This view is strengthened in the Pannonian plain by the presence of a fully developed Chernozem underlying a 6000 year-old kurgen in eastern Hungary (Barczi et al., 2006). Leaching and degradation of Chernozems began during the more humid Atlantic climate prior to the Bronze Age resulting in the formation of Phaeozems (leaching of carbonates) or Luvisols (leaching of carbonates along with clay translocation). This climo-genetic model of Chernozem formation may not be completely valid, however, as radiocarbon dates from some Chernozems suggest they do not all date to the early Holocene and some appear to have developed under conditions not traditionally associated with their formation (e.g., under open forest or steppe-forest vegetation) (Eckmeier et al., 2007).

Multiple episodes of Holocene nonglaciogenic loess deposition have been documented in the central Great plains of the United States and in Saskatchewan, Canada under climatic and environmental conditions that are not dissimilar to the eastern Carpathian Basin (David, 1970; Clayton, Moran, \& Bickley, 1976; Vreeken, 1994; Mason \& Kuzila, 2000; Jacobs \& Mason, 2004). These periods of nonglacigenic loess accumulation are related to increased aridity and/or large magnitude floods that decreased vegetative cover on floodplains promoting renewed aeolian transport of local Pleistocene loess deposits. Mason and Kuzila (2000) identified over $4 \mathrm{~m}$ of Holocene loess deposition in Nebraska (Bignell Loess) that differed lithologically and mineralogically from the underlying Pleistocene Peoria Loess. These differences suggested that the source of the Bignell Loess is dust from local floodplains that contained a mixture of reworked Peoria Loess and silt from older loess deposits. Soils developed in the most recent Bignell Loess deposits (approximately $3 \mathrm{ka}$ ) are classified as Mollisols (Chernozems).

Soil formation in calcareous loess has been extensively studied in the United States and parts of Europe by Ruhe (1984), Pye and Johnson (1988), Markewich et al. (1998), Muhs et al. (2001), Finke and Hutson (2008), and others. These studies report the weathering of primary minerals such as calcite and feldspar along with the loss of soluble elements ( $\mathrm{Ca}$ and $\mathrm{K}$ ) relative to insoluble elements ( $\mathrm{Ti}$ and $\mathrm{Zr}$ ) through leaching (Muhs $\&$ Bettis, 2000; Muhs et al., 2001). If the Pecica deposit is composed primarily of pre-existing soils, geochemical analysis will reveal this deposit to have element concentrations similar to the local Pleistocene loess. Because these loess deposits have undergone a significant period of pedogenesis, the Pecica deposit will consist of previously weathered sediment and will likely have lower concentrations of certain soluble elements or higher concentrations of those elements such as $\mathrm{Al}$ and $\mathrm{Fe}$ that are enriched in soils over time. Additionally, if the proposed Holocene loess identified in the area represents the same stratigraphic unit as the Pecica deposit, they will share similar geochemical and physical characteristics. Previous studies have successfully correlated Pleistocene loess deposits in Iowa using major element concentrations, elemental ratios, and particle size distributions (Muhs \& Bettis, 2000).

\section{METHODS}

In addition to a trench profile in the site of Pecica-Şanţul Mare, we selected two profiles from regional and off-tell contexts representing the range of variation observed in a 2-6 km radius around the archaeological site. Profile descriptions and samples (200 g bulk, $10 \mathrm{~cm}$ blocks) were collected systematically from excavations on and off the tell, and then opportunistically from local road cuts, river bank exposures, and auger tests. The three representative profiles are referred to as Trench 1 (from one of the upper exposures of the Pecica-Şanţul Mare tell excavation); Soil Pit 1 (a soil pit on the off-tell portion of the site to the west of the fortified tell; and Mureş 1 (a bank profile $6 \mathrm{~km}$ downriver on the same landform) (Figures 3, 4). The Mures 1 profile was the farthest from the tell and in both of the offsite profiles, the proposed "Pecica deposit" was observed. Profiles were documented using standard descriptions (Schoeneberger et al., 2002) with all depth measurements as centimeter below surface. Representative samples were subjected to physical and chemical analyses using the standard methods of the National Soil Survey Laboratory (Soil Survey Laboratory Staff, 2004). Particle size was measured using the pipette method, with $\mathrm{H}_{2} \mathrm{O}_{2}$ and $\mathrm{HCl}$ pretreatment for organic matter and 


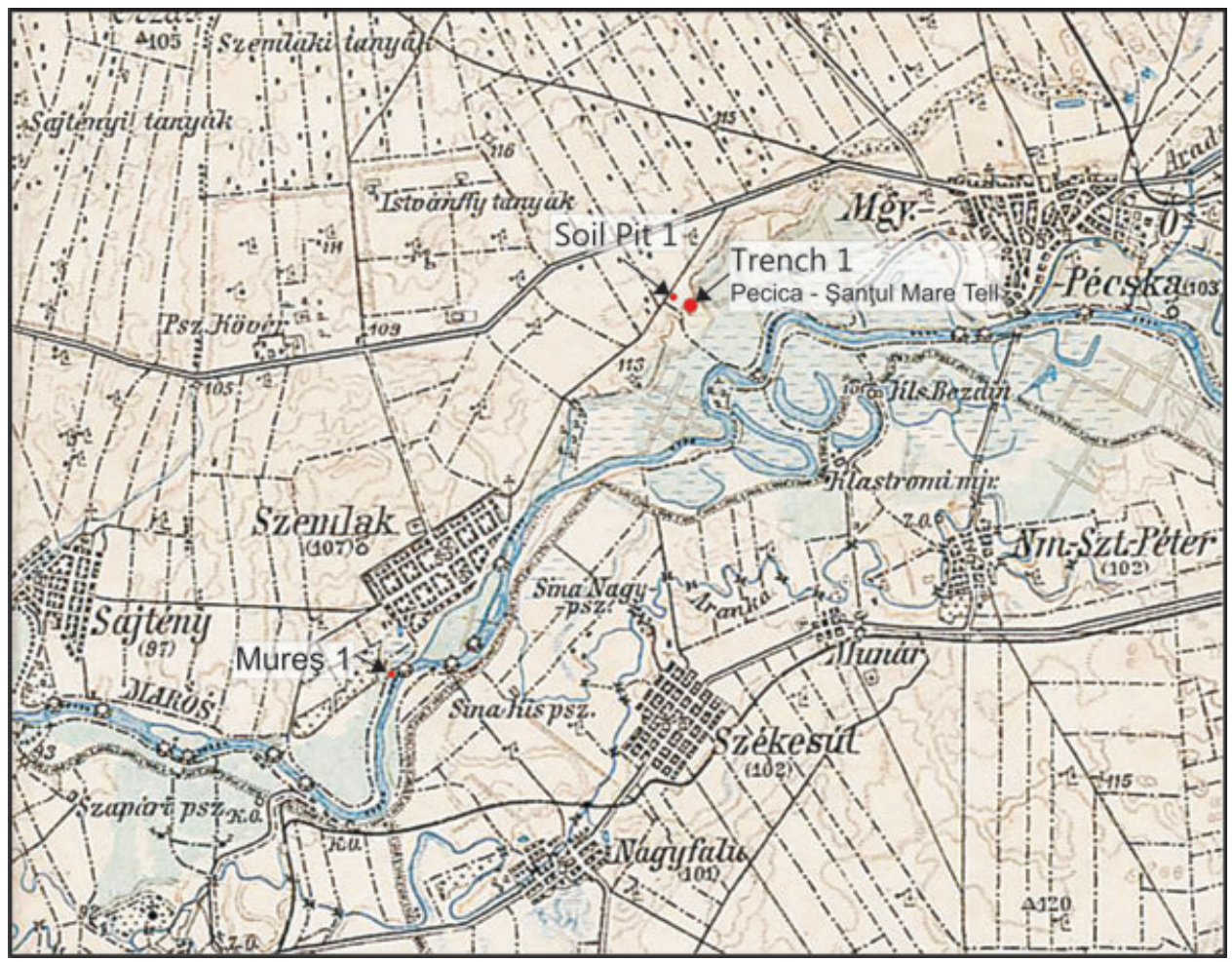

Figure 3 Map of the study area around the site of Pecica_S Sanţul Mare showing the locations of the three profiles used in this study-Trench 1, (part of the excavations at Pecica—Şanţul Mare); Soil Pit 1 (beyond the western edge of the fortified tell); Mureş 1 (downstream on the same landform). Map Source: 1914 Map from the 3rd Military Mapping Survey of Austria-Hungary, (1:200,000) 18.XII.

carbonates. Total element analysis was conducted on the entire $<2 \mathrm{~mm}$ soil fraction ground to pass a \#60 sieve via complete microwave dissolution with strong acids (HF, $\mathrm{HCl}, \mathrm{HNO}_{3}$ ). Element concentrations were measured using inductively coupled argon plasma. Intact soil blocks were embedded in epoxy and ground into 30- $\mu$ m thick large format $(5 \times 7 \mathrm{~cm})$ thin sections. Petrographic analysis of the soil thin sections was performed using plane and cross-polarized light and magnifications of $10 \times$ to $400 \times$ (following Bullock et al., 1985; Stoops, 2003).

\section{RESULTS}

\section{Profile Descriptions}

The profile descriptions for the three representative profiles used in this study are provided in Table I and summarized below. The profile from Trench I on the tell is limited in this study to the upper $164 \mathrm{~cm}$ which consists of two separate upper deposits including a $19 \mathrm{~cm}$ thick plow zone (ACk or Ap) over a $35 \mathrm{~cm} \mathrm{AC} \mathrm{horizon} \mathrm{relating} \mathrm{to} \mathrm{a}$ mixture of Dacio-Roman occupation and historic use of the site and subsequent early 20th century excavations. These deposits overlie the proposed "Pecica deposit," a $\sim 50 \mathrm{~cm}$ thick dark gray (10YR4/1), silt loam to silty clay loam, characterized by carbonate masses and very weak subangular blocky to granular structure. The thickness varied across the tell, averaging $70 \mathrm{~cm}$. Throughout Trench 1, and other sections of the excavation, intrusive Dacio-Roman pits cross-cut this layer (visible in Figure 4a). This dark gray, massive Pecica deposit overlies up to $4 \mathrm{~m}$ of complex archaeological stratigraphy that makes up the Bronze Age component of the tell (Table I). All of the deposits, including the proposed Pecica deposit (Layer 7, 3Btk, elsewhere labeled Zone B2 in O'Shea et al., 2005: Figure 3), contain artifacts and some coarse material including coarse sand and pebbles. Beginning with Layer $8 \mathrm{~b}$ (see Table I) the complex archaeological deposits include burned zones, floors, and mixed ash and charcoal deposits resulting from intensive MBA tell occupation (O'Shea et al., 2005).

Soil Pit 1 is located north of the tell approximately $200 \mathrm{~m}$, in what is now an intensively cultivated area of a Pleistocene terrace (Table I). The profile revealed two soils developed in calcareous aeolian sediments. Only the top $20 \mathrm{~cm}$ of the lower soil was exposed in the $170 \mathrm{~cm}$ deep pit. This soil consists of a dark yellowish brown (10YR4/6) silt loam, 2Btk horizon with strong medium 


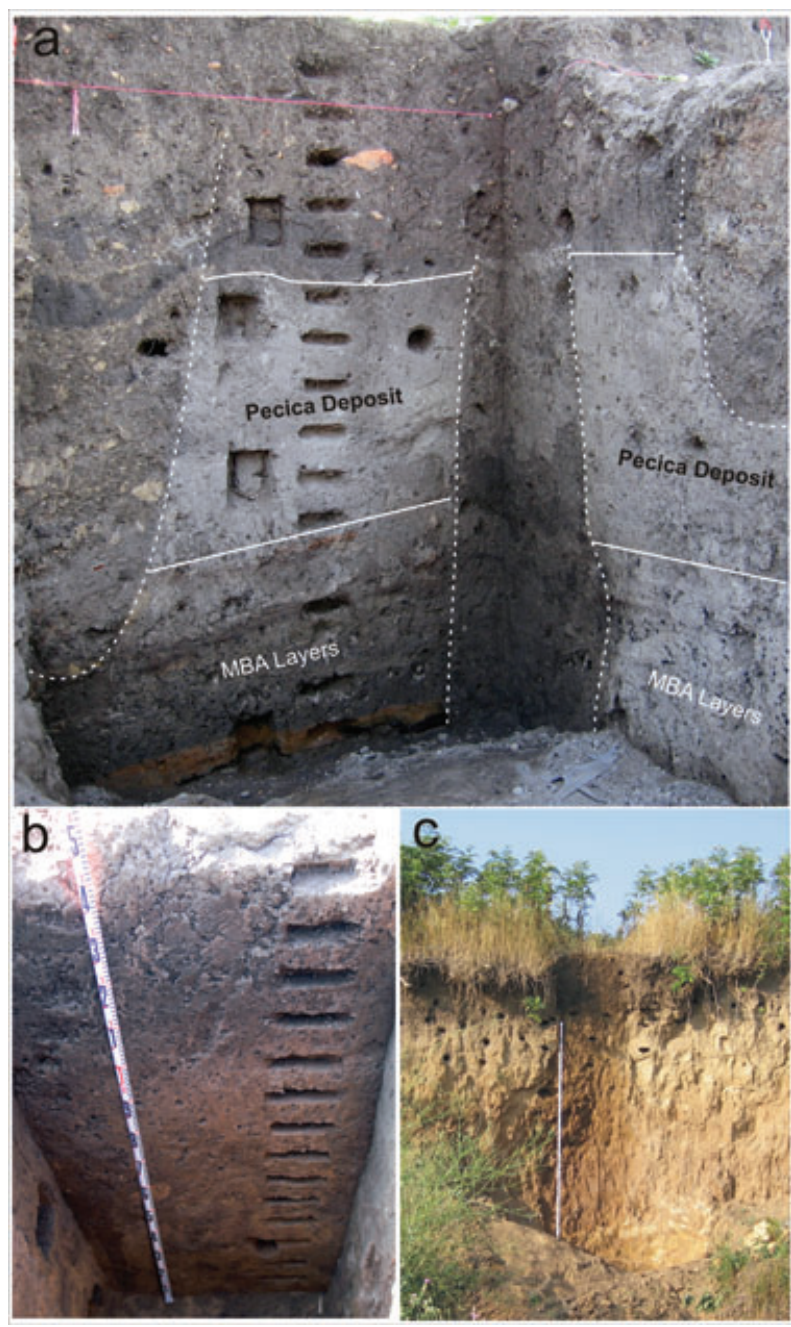

Figure 4 Photographs of each profile analyzed. (a) Trench 1-Northeast corner of Trench 1 from the tell site of Pecica-Şanţul Mare. Labels indicate the Pecica deposit overlying the MBA layers. Note the intrusive pits (previous excavations and Dacio-Roman pits are indicated by dotted white lines. The profile is $180 \mathrm{~cm}$ high. (b) Soil Pit 1-located $200 \mathrm{~m}$ west, off-tell. (c) Mureş 1 -located approximately $6 \mathrm{~km}$ downstream near the village of Semlac. The dark holes in the profile are modern birds' nests. The full profile height is $290 \mathrm{~cm}$

subangular blocky structure and common carbonate filaments and few nodules. The overlying soil from 0 to $150 \mathrm{~cm}$ (proposed Holocene loess parent material-Pecica deposit) consists of black to very dark gray (2.5Y2.5 to 3/1) silty clay loam, containing one, perhaps two, Ap horizons from 0 to $52 \mathrm{~cm}$. These horizons overlay, in order, two light olive brown (2.5Y5/4), a dark yellowish brown (10YR4/4), and a light olive brown (2.5YR4/4) silty clay loam, Btk horizons with moderate medium subangular structure and few filaments and nodules.

The Mureş Profile (Mureş 1) located approximately $6 \mathrm{~km}$ downstream from the site (Trench 1), on the same landform (Pleistocene terrace overlooking the Mureş floodplain) contains two distinct soils developed in calcareous loess (Table I). The lower, buried soil (herein called the Mureş Paleosol) from 130 to $285+\mathrm{cm}$, consists of brown to dark yellowish brown (10YR4/4-3) silty clay loam to silty clay, $2 \mathrm{Btkb}$ horizons with strong medium prismatic structure, and many fine carbonate filaments along pore walls over a 2.5Y6/4 silt loam C horizon. Few to common moderately cemented fine-to-medium carbonate nodules are present throughout the paleosol. The overlying soil from 0 to $130 \mathrm{~cm}$ (proposed Holocene loess/Pecica deposit) consists of black to very dark gray (10YR2/1-3/1) silty clay loam Ap horizons from 0 to $48 \mathrm{~cm}$, and dark yellowish brown (10YR4/4) silty clay loam Bk horizons with moderate medium subangular to moderate medium prismatic structure.

\section{Particle Size Analysis}

Particle size data are reported in Table II and illustrated in Figure 5. These data show the Pecica deposit in Trench 1 is composed of $59-64 \%$ silt (2-50 microns), $24-30 \%$ clay ( $<2$ microns), and $10-14 \%$ sand (>50 microns). The deposit is generally homogenous; however, there is a slight increase in sand and decrease in silt with depth. The proposed Holocene loess deposit in the surrounding area $(52-150 \mathrm{~cm}$ in Soil Pit 1) consists of $57-68 \%$ silt, $28-39 \%$ clay, and $3-6 \%$ sand. In the Mureş 1 profile, the proposed Holocene loess deposit is characterized by a general decrease in clay and generally similar percent in fine silt to a depth of $120 \mathrm{~cm}$. In this same profile from 120 to $200 \mathrm{~cm}$, there is a steady decrease in clay and an increase in fine silt. This trend is similar to Soil Pit 1 which has a steady decrease shifting to an increase in clay and general increase in fine silt to a depth of $100 \mathrm{~cm}$, at which point clay content begins to increase and total silt decreases. Comparisons of the silt fractions between the off-tell soil profiles and the profile on the tell display similar distributions with depth (Figure 5).

\section{Geochemical Analyses}

Chemical analyses were performed on all samples collected from the Trench 1 and Mureş 1 profiles. Selected oxide results are listed in Table III. The mean percentages of the major oxides of $\mathrm{Al}, \mathrm{Ca}, \mathrm{K}, \mathrm{Fe}, \mathrm{Ti}$, and $\mathrm{Mg}$ in the samples collected from the Pecica deposit at 70-110 cm in Trench 1, and from the proposed Holocene loess at 60 $120 \mathrm{~cm}$, from the Mureş 1 profile are shown in graphic form in Figure 6. Also included in Figure 6 are the oxide percents for a sample of the buried Mureş Paleosol parent material ( $\mathrm{C}$ horizon at $285 \mathrm{~cm}$, noted above). It is evident from these data that the chemical compositions 
Table I Soil morphology. Shaded rows indicate horizons/layers proposed as directly related to the Pecica deposit.

\begin{tabular}{|c|c|c|c|c|c|c|}
\hline Soil & Horizon $\left(\mathrm{L}=\right.$ Layer $^{\mathrm{a}}$ & Depth (cmbs) & Color (moist) & Texture & Structure & $\mathrm{CaCO}_{3}$ concentrations \\
\hline \multirow[t]{10}{*}{ Trench $1^{\mathrm{a}}$} & L1 (ACk) & $0-19$ & 7.5YR2.5/2 & sil & $2 m g r$ & Common filaments \\
\hline & L1b (BCk) & $19-54$ & $7.5 Y R 3 / 2$ & sil-sicl & $2 m g r$ & Common filaments and nodules \\
\hline & L6 (2BCk) & $54-66$ & 10YR2/2 & sil & $1 \mathrm{mgr}$ & Common filaments \\
\hline & L7 (3BCk) "Pecica deposit" & $66-114$ & 10YR4/1 & sicl-sil & $1 \mathrm{mgr}$ & Common filaments \\
\hline & L8b (4BCk) & $114-128$ & 10YR4/2 & sil & $\mathrm{m}$ & Few filaments \\
\hline & L8C (5BCk) & $128-132$ & 7.5YR3/2 & sil & $\mathrm{m}$ & Few filaments \\
\hline & L8d (6BCk) & $132-144$ & $2.5 Y 4 / 2$ & sil & $\mathrm{m}$ & Few filaments \\
\hline & L8e (7BCk) & $144-148$ & $2.5 Y 5 / 3$ & sil & m & Few filaments \\
\hline & L8f (8BCk) & $148-158$ & 10YR4/2 & sil & m & Few filaments \\
\hline & $\operatorname{L8g}(9 B C)$ & $158-164$ & $7.5 Y R 4 / 6$ & sil & m & \\
\hline \multirow[t]{7}{*}{ Soil Pit 1} & Ap & $0-18$ & $2.5 Y 2.5 / 1$ & sicl & $3 m g r$ & \\
\hline & A1 & $18-52$ & $2.5 Y 3 / 2$ & sicl & $2 \mathrm{msbk}$ & \\
\hline & $\mathrm{A} / \mathrm{Bk}$ & $52-67$ & $2.5 Y 3 / 3$ & sicl & $2 \mathrm{msbk}$ & \\
\hline & Btk1 & $67-102$ & $2.5 Y 5 / 4$ & sicl & $2 \mathrm{msbk}$ & Many filaments and nodules \\
\hline & Btk2 & $102-125$ & $10 Y R 5 / 4$ & sicl & $2 \mathrm{msbk}$ & Common filaments and nodules \\
\hline & Btk3 & $125-150$ & $2.5 Y 4 / 4$ & sil & $2 \mathrm{msbk}$ & Few filaments and nodules \\
\hline & 2Btk & $150-170+$ & 10YR4/6 & sil & 3msbk & Common filaments and nodules \\
\hline \multirow[t]{4}{*}{ Mureş 1} & Ap1 & $0-14$ & 10YR2/1 & sicl & $3 m g r$ & \\
\hline & Ap2 & $14-48$ & 10YR3/1 & sicl & $3 m g r$ & \\
\hline & $\mathrm{Bk} 1$ & $48-96$ & 10YR4/4 & sicl & $2 \mathrm{msbk}$ & Common filaments \\
\hline & $\mathrm{Bk} 2$ & $96-130$ & $10 Y R 4 / 4$ & sicl & $2 \mathrm{msbk}$ & Common filaments \\
\hline \multirow[t]{4}{*}{ Mureş Paleosol } & 2Btk1b & $130-162$ & 10YR4/4 & sicl & $3 m p r s m$ & Common fine filaments \\
\hline & $2 \mathrm{Bk} 1 \mathrm{~b}$ & $162-202$ & $10 Y R 4 / 3$ & Sic & 3mprsm & Many filaments and nodules \\
\hline & $2 \mathrm{Bk} 2 \mathrm{~b}$ & $202-255$ & 10YR4/4 & sicl & $3 m p r s m$ & Common filaments and nodules \\
\hline & $2 \mathrm{C}$ & $255-285+$ & $2.5 Y 6 / 4$ & sil & Massive & Irregular masses \\
\hline
\end{tabular}

aLayers in Trench 1 described in the field using standardized soil terminology, however, most of these strata are not technically soil horizons since several are relatively unweathered anthropogenic deposits. Therefore, both archaeological layer and horizon designations are given. Note that Layers are assigned consecutively for simplicity but do not match the originals from O'Shea et al. (2005).

of the Pecica deposit and the proposed Holocene loess at Mureş 1 are quite similar; evidence for a common origin. Conversely, the chemical makeup of the $\mathrm{C}$ horizon at the base of the Mureş Paleosol exhibits substantially lower concentrations of $\mathrm{Al}$ and $\mathrm{Ca}$ oxides and a higher concentration of $\mathrm{Mg}$ oxide than the soils above and in Trench 1. Given the fact that $\mathrm{Al}$ is extremely insoluble in the weathering environment, the lower value for $\mathrm{Al}$ in the older material strongly points to a different parent material for this earlier soil.

Plots of the ratios of $\mathrm{CaO}$ to $\mathrm{TiO}_{2}$ with depth for the Trench 1 and Mureş 1 profiles are shown in Figure 7. Brackets are used to show the vertical extent of the Pecica deposit. Evident in Figure 7 are the generally higher $\mathrm{CaO} / \mathrm{TiO}_{2}$ ratios for the Trench 1 Pecica deposit compared with the proposed Holocene loess at Mureş 1. This difference is most evident in the upper levels of the deposits. A likely explanation for this difference lies in the fact that the Pecica deposit is overlain by Dacio-Roman aged anthopogenic material that has tended to protect the surface of the Pecica deposit from direct exposure to intense weathering at the land surface and enriched it with other cations. Despite this difference, the upper $160 \mathrm{~cm}$ of each profile exhibit similar trends with depth, that is, the $\mathrm{CaO} / \mathrm{TiO}_{2}$ ratio starts out relatively low, increases to a maximum value in the depth interval from 50 to $100 \mathrm{~cm}$, then decreases to a low at $150 / 160 \mathrm{~cm}$. This pattern is congruent with the field descriptions and particle size distributions contained in Tables I and II. It is also consistent with the existence of an unconformity at approximately $150 \mathrm{~cm}$ where a period of weathering reduced the $\mathrm{CaO} / \mathrm{TiO}_{2}$ ratio through solution and removal of the $\mathrm{Ca}$, followed by a period of deposition of fresh aeolian sediment, likely during the Holocene. Subsequent weathering has undoubtedly been removing the highly mobile $\mathrm{Ca}$ in the upper levels of each deposit to the present day, accounting for the low $\mathrm{CaO} / \mathrm{TiO}_{2}$ values at and near the surfaces.

Figure 8 provides further evidence of the presence of an unconformity with the distribution of K. Nutrients which are essential for plant growth tend to accumulate near the soil surface over time (Kirby, 1985). This occurs as plants extract nutrients from the soil, incorporate these nutrients into their biomass, fulfill their lifecycle, and finally return the nutrients to the soil surface following death. One of the most strongly biocycled elements is K (Porder \& Chadwick, 2009). Globally it has been found that this element tends to be highly concentrated in the 
Table II Particle size data by profile. Shaded rows indicate horizons/layers proposed as directly related to the "Pecica deposit."

\begin{tabular}{|c|c|c|c|c|c|c|c|c|c|}
\hline Soil & Depth (cmbs) & \% Clay & $\%$ Fine silt & $\%$ Coarse silt & $\%$ Very fine sand & $\%$ Fine sand & $\%$ Medium sand & $\%$ Coarse sand & $\begin{array}{c}\% \text { Very } \\
\text { coarse sand }\end{array}$ \\
\hline \multicolumn{10}{|l|}{ Trench $1^{a}$} \\
\hline Layer 1b (AC) & 50 & 30.5 & 33.8 & 25.6 & 3.9 & 1.9 & 0.8 & 1.6 & 2.0 \\
\hline Layer 6 (2BCk) & 60 & 29.2 & 32.6 & 26.3 & 4.3 & 2.1 & 1.1 & 2.0 & 2.3 \\
\hline Layer 7 (3BCK) & 70 & 25.7 & 36.5 & 26.3 & 4.7 & 2.4 & 1.1 & 1.9 & 1.7 \\
\hline \multirow[t]{4}{*}{ "Pecica deposit" } & 80 & 27.8 & 34.2 & 27.3 & 4.2 & 2.0 & 1.3 & 1.6 & 1.9 \\
\hline & 90 & 24.4 & 35.9 & 28.4 & 4.4 & 2.2 & 1.1 & 1.6 & 2.1 \\
\hline & 100 & 24.5 & 35.6 & 25.5 & 4.9 & 2.5 & 1.3 & 2.7 & 2.7 \\
\hline & 110 & 26.5 & 34.1 & 24.6 & 5.4 & 2.8 & 1.3 & 2.5 & 2.6 \\
\hline \multicolumn{10}{|l|}{ Soil Pit 1} \\
\hline Ap & 10 & 35.7 & 30.2 & 28.6 & 3.3 & 0.7 & 0.4 & 0.4 & 0.3 \\
\hline A1 & 20 & 35.8 & 28.9 & 30.2 & 3.3 & 0.7 & 0.5 & 0.6 & 0.2 \\
\hline A1 & 30 & 35.7 & 28.2 & 31.0 & 3.3 & 0.7 & 0.4 & 0.5 & 0.2 \\
\hline $\mathrm{A} 1$ & 40 & 34.4 & 31.7 & 29.3 & 3.2 & 0.7 & 0.3 & 0.3 & 0.0 \\
\hline A1 & 50 & 35.6 & 30.1 & 30.5 & 3.0 & 0.5 & 0.1 & 0.1 & 0.1 \\
\hline $\mathrm{A} / \mathrm{Bk}$ & 60 & 33.4 & 31.6 & 30.0 & 3.9 & 0.6 & 0.1 & 0.1 & 0.0 \\
\hline Btk1 & 80 & 30.5 & 33.8 & 31.3 & 3.8 & 0.5 & 0.1 & 0.1 & 0.0 \\
\hline Btk1 & 90 & 27.5 & 36.6 & 31.1 & 4.0 & 0.5 & 0.2 & 0.1 & 0.1 \\
\hline Btk1 & 100 & 27.0 & 35.6 & 32.5 & 4.2 & 0.5 & 0.1 & 0.0 & 0.0 \\
\hline Btk2 & 110 & 29.8 & 33.4 & 32.0 & 4.1 & 0.5 & 0.1 & 0.0 & 0.0 \\
\hline Btk2 & 120 & 32.6 & 31.1 & 32.3 & 3.2 & 0.5 & 0.1 & 0.1 & 0.1 \\
\hline Btk3 & 130 & 32.3 & 31.5 & 32.1 & 3.2 & 0.5 & 0.2 & 0.1 & 0.0 \\
\hline Btk3 & 140 & 39.4 & 30.6 & 26.6 & 2.3 & 0.6 & 0.3 & 0.1 & 0.1 \\
\hline 2Btk & 150 & 41.7 & 29.8 & 24.5 & 2.5 & 0.7 & 0.4 & 0.1 & 0.1 \\
\hline 2Btk & 160 & 41.0 & 29.9 & 25.2 & 2.2 & 0.7 & 0.6 & 0.3 & 0.1 \\
\hline \multicolumn{10}{|l|}{ Mureş 1} \\
\hline Ap1 & 10 & 34.9 & 30.5 & 28.9 & 3.2 & 0.9 & 0.4 & 0.6 & 0.2 \\
\hline Ap2 & 30 & 34.5 & 30.6 & 29.7 & 3.3 & 0.7 & 0.5 & 0.4 & 0.4 \\
\hline Bk1 & 60 & 30.4 & 32.7 & 31.8 & 4.2 & 0.5 & 0.2 & 0.2 & 0.0 \\
\hline Bk1 & 75 & 30.5 & 31.3 & 33.5 & 3.7 & 0.5 & 0.1 & 0.1 & 0.0 \\
\hline Bk1 & 90 & 28.5 & 32.7 & 34.2 & 3.9 & 0.5 & 0.2 & 0.1 & 0.0 \\
\hline Bk2 & 105 & 29.2 & 32.0 & 33.6 & 4.1 & 0.6 & 0.1 & 0.0 & 0.0 \\
\hline Bk2 & 120 & 31.2 & 30.7 & 33.4 & 3.9 & 0.5 & 0.2 & 0.1 & 0.0 \\
\hline 2Btkb1 & 135 & 36.2 & 29.9 & 29.7 & 3.1 & 0.5 & 0.3 & 0.2 & 0.0 \\
\hline 2Btkb1 & 150 & 40.0 & 30.3 & 27.0 & 1.5 & 0.5 & 0.4 & 0.3 & 0.1 \\
\hline 2Btkb2 & 165 & 39.5 & 30.7 & 25.7 & 2.9 & 0.7 & 0.4 & 0.3 & 0.0 \\
\hline 2Btkb2 & 180 & 40.0 & 27.6 & 27.8 & 3.2 & 0.6 & 0.3 & 0.2 & 0.0 \\
\hline 2Btkb2 & 195 & 41.2 & 26.7 & 28.1 & 3.3 & 0.5 & 0.2 & 0.1 & 0.0 \\
\hline 2Btkb3 & 210 & 39.5 & 27.4 & 30.2 & 2.2 & 0.00 & 0.0 & 0.0 & 0.0 \\
\hline 2Btkb3 & 225 & 33.4 & 30.5 & 31.0 & 4.5 & 0.3 & 0.1 & 0.0 & 0.0 \\
\hline 2Btkb3 & 240 & 32.9 & 30.3 & 32.8 & 3.3 & 0.3 & 0.1 & 0.0 & 0.0 \\
\hline 2Btkb3 & 255 & 28.5 & 31.9 & 35.4 & 3.9 & 0.1 & 0.0 & 0.0 & 0.0 \\
\hline $2 C$ & 270 & 28.4 & 31.8 & 36.4 & 3.3 & 0.1 & 0.0 & 0.0 & 0.0 \\
\hline $2 \mathrm{C}$ & 285 & 24.2 & 34.4 & 36.8 & 4.5 & 0.2 & 0.0 & 0.0 & 0.0 \\
\hline
\end{tabular}

a Note that Layers are assigned consecutively for simplicity but do not match the originals from o'Shea et al. (2005).

upper $20 \mathrm{~cm}$ of the soil profile suggesting plant biocycling plays a critical role in the vertical distribution of essential nutrients (Jobbagy \& Jackson, 2001).

Because plants alter the vertical distribution of these elements over time their concentration with depth in the soil profile can be used to locate buried land surfaces that were at one time colonized by plants (Kirby, 1985; Lewis et al., 1993). In the Mureş profile, concentrations of $\mathrm{K}$ increase at the proposed unconformity between the late
Pleistocene and Holocene loess (Figure 8). This further supports that two episodes of leoss deposition have occurred and are separated by a pedogenic (missing time) unconformity.

\section{Micromorphology Analysis}

Unlike the other forms of data, the thin section observations are not about matching the off-site profiles with 


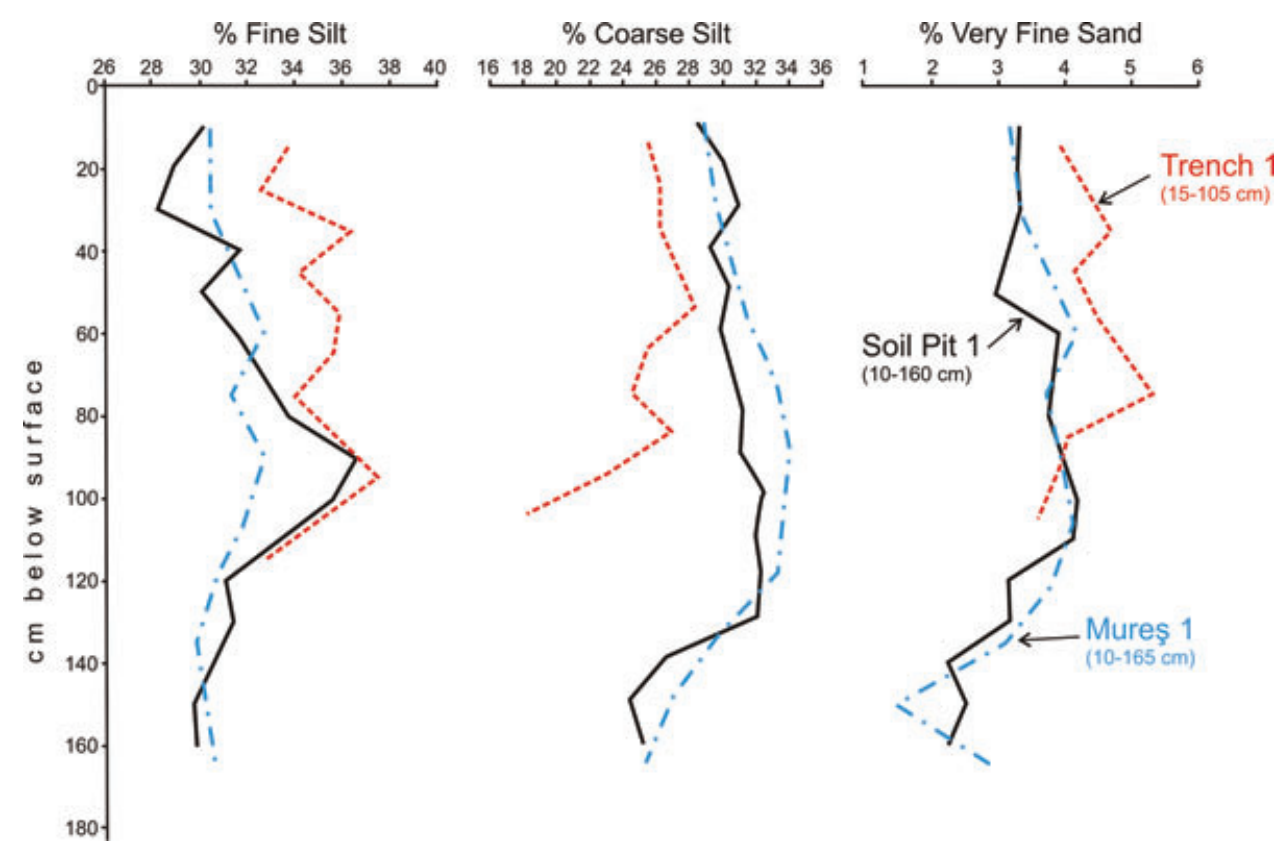

Figure 5 Particle size fractions by depth for each profile—-Trench 1 (Pecica deposit), Soil Pit 1, and Mureş 1.

the Pecica deposit as they are determining the contents of the deposit relative to other anthropogenic materials on the tell. The Trench 1 profile revealed a deposit composed of calcareous silt homogenized by bioturbation (Figure 9a, b). The deposit is composed primarily of siltsized polymineral clastic sediments (predominantly silica and carbonate) suggestive of aeolian sediments derived from the local Mureş floodplain and/or the surrounding plateau (Figure 9c, d). As noted above, the original suggested anthropogenic source for the Pecica deposit included extensive burning and should therefore include ash from initial Dacio-Roman activities on the site. While Dacio-Roman artifacts have been found in the Pecica deposit, there is no evidence for significant amounts of wood or dung ash or charcoal that might signify a largescale burning event(s). The absence of these sediments cannot be attributed to the post-depositional environment since the underlying MBA deposits and the intrusive Dacio-Roman pits have abundant evidence for ash from both wood and dung.

\section{Chronology}

It is difficult to directly date an aeolian deposit that has been impacted by subsequent anthropogenic activities (as in Trench 1). Here, we rely on a series of radiocarbon dates and the presence/absence of soil formation to bracket the Pecica deposit. At its lower boundary the stratum abruptly overlies the last MBA deposits on the tell. A suite of seven AMS-based radiocarbon dates establish the terminus post quem for the deposit at some time in the 16-17th century B.C. Calculated intercepts with the INTCAL04 calibration curve date to the 17th century B.C., with two-sigma (95\% probability) calibrated results extending into the 16th century B.C. (O'Shea et al., 2005, 2006, 2011). There is no evidence for later MBA or Late Bronze Age (LBA) occupations at the site based on either chronometric samples or artifactual evidence, and these dates correspond with the abandonment of the downstream Hungarian tell of Klárafalva-Hajdova (O'Shea, 1992, provides a chronometric framework for MBA site occupations in the area), where a visually similar deposit has been reported immediately above the MBA occupation layers. Contemporaneity of the sites is also indicated by matching archaeomagnetic series from a burned horizon in Soil Pit 3 at Pecica and an archaeomagnetic series from F12 at Klárafalva-Hajdova (Lengyel, 2010:6), radiocarbon dated to the 17th century B.C. (Beta 231051670 B.C. \pm 80$)$.

The Pecica deposit is capped and intruded by later Dacio-Roman layers; AMS-based radiocarbon dates associated with a series of large intrusive Dacian pits place this occupation as early as the 4th century B.C. (O'Shea et al., 2006). These pits also produced wheel-turned pottery, a technology which does not appear in the Carpathian Basin until the 6th century B.C. The MBA abandonment at Pecica appears to have been fairly abrupt based on the nature of the stratigraphy and the absence of any LBA. Current data suggest that the center collapses, with only brief scattered settlement, followed 
Table III Total element concentrations from the Trench 1 and Mureş 1 profiles. Shaded rows indicate horizons/layers proposed as directly related to the "Pecica deposit."

\begin{tabular}{|c|c|c|c|c|c|c|c|c|c|c|c|}
\hline Horizon depth (cmbs) & Sample depth & $\mathrm{ZrO}_{2}(\%)$ & $\mathrm{Al}_{2} \mathrm{O}_{3}(\%)$ & $\mathrm{CaO}(\%)$ & MgO (\%) & $\mathrm{Na}_{2} \mathrm{O}(\%)$ & $\mathrm{K}_{2} \mathrm{O}(\%)$ & $\mathrm{Fe}_{2} \mathrm{O}_{3}(\%)$ & $\mathrm{TiO}_{2}(\%)$ & $\mathrm{P}_{2} \mathrm{O}_{5}(\%)$ & $\mathrm{MnO}(\%)$ \\
\hline \multicolumn{12}{|l|}{ Trench $1^{a}$} \\
\hline Layer 1 (ACk) & 10 & 0.0054 & 15.17 & 7.11 & 1.75 & 1.367 & 2.43 & 0.426 & 1.682 & 1.48 & 0.106 \\
\hline \multirow[t]{4}{*}{ Layer 1b (BCk) } & 20 & 0.0052 & 15.64 & 7.73 & 1.76 & 1.353 & 2.37 & 0.438 & 1.684 & 1.31 & 0.111 \\
\hline & 30 & 0.0057 & 16.45 & 8.18 & 1.91 & 1.428 & 2.43 & 0.439 & 1.766 & 1.23 & 0.104 \\
\hline & 40 & 0.0058 & 15.09 & 7.16 & 1.83 & 1.386 & 2.42 & 0.427 & 1.720 & 1.29 & 0.108 \\
\hline & 50 & 0.0051 & 13.17 & 6.26 & 1.82 & 1.346 & 2.44 & 0.429 & 1.715 & 1.62 & 0.116 \\
\hline Layer 6 (2BCk) & 60 & 0.0051 & 19.23 & 10.50 & 2.01 & 1.329 & 2.30 & 0.398 & 1.655 & 1.81 & 0.101 \\
\hline \multirow[t]{5}{*}{ Layer 7 (3BCK) "Pecica deposit" } & 70 & 0.0045 & 21.12 & 11.86 & 2.06 & 1.315 & 2.28 & 0.391 & 1.548 & 1.98 & 0.104 \\
\hline & 80 & 0.0048 & 19.83 & 10.60 & 2.18 & 1.258 & 2.39 & 0.388 & 1.608 & 1.84 & 0.103 \\
\hline & 90 & 0.0050 & 19.83 & 12.58 & 2.23 & 1.289 & 2.40 & 0.392 & 1.514 & 1.52 & 0.093 \\
\hline & 100 & 0.0048 & 20.44 & 11.70 & 2.22 & 1.260 & 2.57 & 0.391 & 1.619 & 1.63 & 0.096 \\
\hline & 110 & 0.0048 & 20.22 & 12.56 & 2.25 & 1.227 & 2.59 & 0.374 & 1.490 & 1.85 & 0.103 \\
\hline Layer 8c (5BCk) & 130 & 0.0053 & 17.04 & 10.68 & 2.32 & 1.270 & 2.91 & 0.387 & 1.545 & 1.64 & 0.103 \\
\hline Layer 8g (9BCk) & 160 & 0.0036 & 16.28 & 8.70 & 1.66 & 1.344 & 3.70 & 0.447 & 1.928 & 1.49 & 0.122 \\
\hline \multicolumn{12}{|l|}{ Mureş 1} \\
\hline Ap (0-14) & 15 & 0.0072 & 11.9 & 2.18 & 1.6 & 1.48 & 2.30 & 0.50 & 2.14 & 0.43 & 0.11 \\
\hline A (14-48) & 30 & 0.0075 & 12.5 & 3.95 & 1.7 & 1.48 & 2.22 & 0.50 & 2.23 & 0.35 & 0.11 \\
\hline \multirow[t]{3}{*}{ Bk1 (48-96) } & 60 & 0.0065 & 21.1 & 12.52 & 2.4 & 1.46 & 1.90 & 0.46 & 1.94 & 0.19 & 0.09 \\
\hline & 75 & 0.0067 & 21.1 & 12.06 & 2.6 & 1.47 & 1.91 & 0.46 & 1.98 & 0.18 & 0.09 \\
\hline & 90 & 0.0067 & 20.4 & 11.48 & 2.9 & 1.53 & 1.95 & 0.46 & 1.97 & 0.17 & 0.09 \\
\hline \multirow[t]{2}{*}{ Bk2 (96-130) } & 105 & 0.0086 & 16.9 & 8.10 & 2.7 & 1.50 & 2.04 & 0.49 & 2.25 & 0.17 & 0.10 \\
\hline & 120 & 0.0077 & 17.1 & 8.20 & 2.8 & 1.58 & 2.08 & 0.49 & 2.30 & 0.16 & 0.09 \\
\hline \multirow[t]{2}{*}{ 2Btkb1 (130-162) } & 135 & 0.0084 & 13.8 & 3.47 & 2.6 & 1.60 & 2.16 & 0.56 & 2.41 & 0.16 & 0.10 \\
\hline & 150 & 0.0085 & 14.2 & 1.83 & 2.5 & 1.46 & 2.25 & 0.59 & 2.54 & 0.15 & 0.12 \\
\hline \multirow[t]{3}{*}{ 2Btkb2 (162-202) } & 165 & 0.0081 & 14.4 & 4.74 & 2.4 & 1.48 & 2.13 & 0.56 & 2.50 & 0.15 & 0.10 \\
\hline & 180 & 0.0081 & 19.2 & 9.67 & 2.2 & 1.42 & 1.91 & 0.49 & 2.34 & 0.13 & 0.09 \\
\hline & 195 & 0.0083 & 19.7 & 10.14 & 2.2 & 1.28 & 1.79 & 0.49 & 2.34 & 0.13 & 0.08 \\
\hline \multirow{2}{*}{ 2Btkb3 (202-255) } & 240 & 0.0079 & 18.5 & 9.34 & 2.8 & 1.30 & 1.85 & 0.48 & 2.27 & 0.13 & 0.09 \\
\hline & 255 & 0.0083 & 17.5 & 8.83 & 3.3 & 1.48 & 1.88 & 0.46 & 2.29 & 0.13 & 0.09 \\
\hline \multirow[t]{2}{*}{$3 C(255-285)$} & 270 & 0.0078 & 15.9 & 8.25 & 3.9 & 1.40 & 1.79 & 0.44 & 2.25 & 0.12 & 0.09 \\
\hline & 285 & 0.0078 & 13.9 & 5.90 & 4.4 & 1.80 & 2.04 & 0.50 & 2.50 & 0.15 & 0.09 \\
\hline
\end{tabular}

${ }^{a}$ Note that Layers are assigned consecutively for simplicity but do not match the originals from O'Shea et al. (2005).

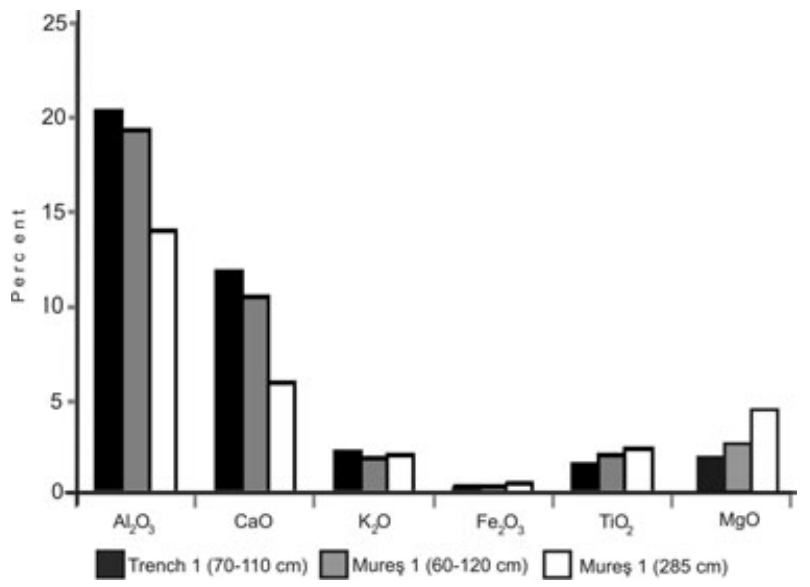

Figure 6 Major oxide concentrations for Trench 1 (averaged for 70$110 \mathrm{~cm}$, Pecica deposit), and Mureş 1 (averaged for 60-120 cm), and the Mureş 1 buried Paleosol C horizon (2Btkb at $285 \mathrm{~cm}$ ). by complete abandonment. We propose, based on both the abrupt contact at the top of the MBA component at Pecica and the absence of soil formation below this contact, that the loess was deposited fairly quickly following MBA site abandonment.

\section{DISCUSSION}

Comparisons of particle size between the Pecica deposit (Trench 1) and the surrounding loess indicate several similarities (Table II, Figure 5). The distribution of fine silt with depth in the Pecica deposit in Trench 1 displays trends that are similar to the proposed Holocene loess/Pecica deposit in Soil Pit 1 and the Mureş Profile (particularly Soil Pit 1), suggesting this distribution is not simply derived from anthropogenic processes. The increase in fine silt with depth along with the sudden 


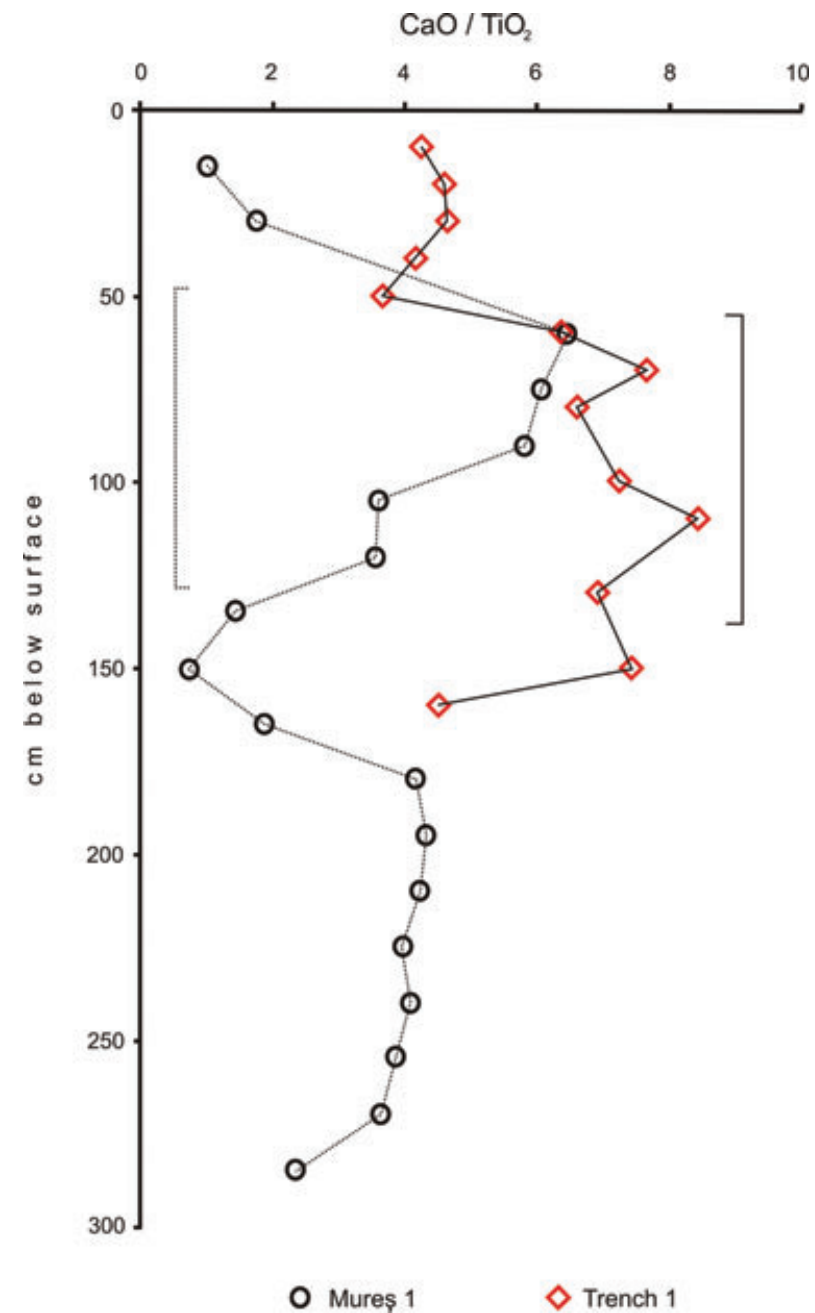

Figure $7 \mathrm{CaO} / \mathrm{TiO}_{2}$ with depth for Trench 1 and the Mureş 1 profile. The solid bracket indicates the data for the Pecica deposit in Trench 1 and the dashed bracket shows that of the Mureş 1 upper loess soil.

increase at approximately the same depth $(90-95 \mathrm{~cm})$ in Trench 1 and Soil Pit 1 suggest these deposits are the result of the same event. The Pecica deposit on the tell in Trench 1 does, however, have slightly lower clay content, and $5-7 \%$ more sand compared to the other deposits (Table II). This increase in sand may be related in part to the distance from the deflation area (source of aeolian sediment). Sand would have been deposited closer to the source area particularly on a topographic barrier with a rough or vegetated surface (Pye, 1995). The coarse and very coarse sand in the Pecica deposit in Trench 1 is unlikely to have been transported any great distance by wind and may possibly be influenced by subsequent habitation and bioturbation processes. The presence of coarse sediments (including microartifacts) likely resulted from human occupation during the initial deposition of the

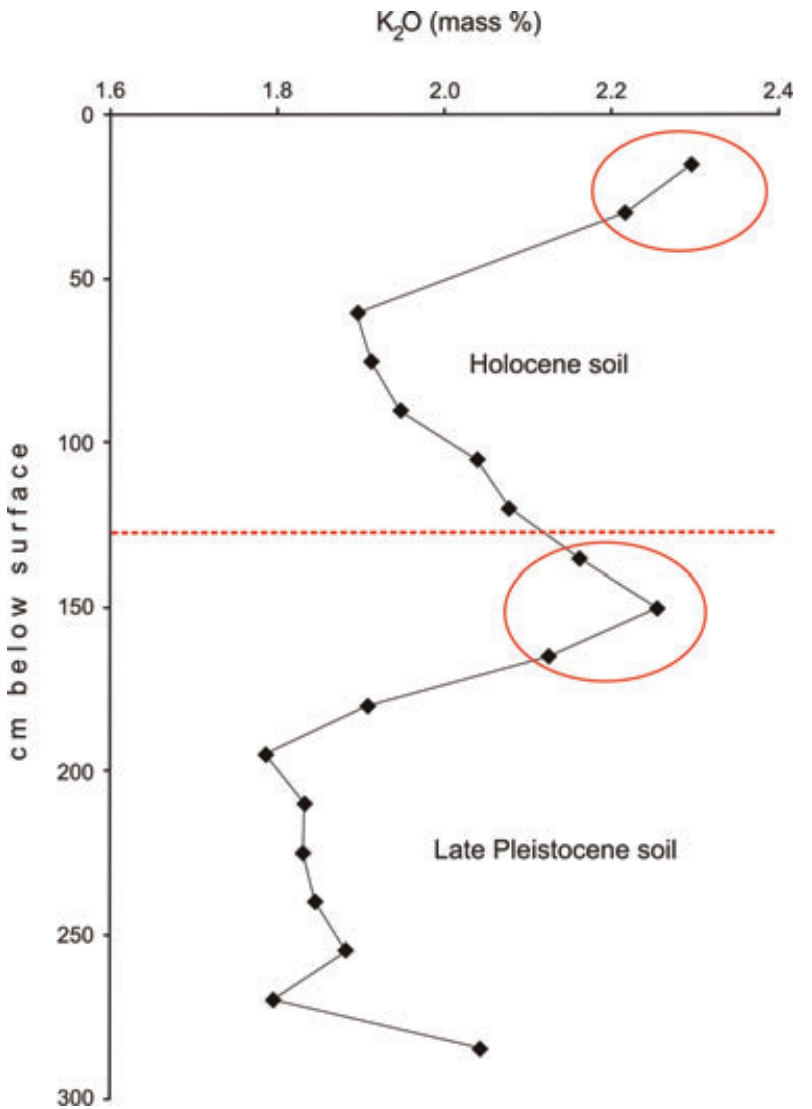

Figure $8 \mathrm{~K}_{2} \mathrm{O}$ distribution with depth in the Mureş 1 profile. The $\mathrm{K}_{2} \mathrm{O}$ peaks likely indicate plant cycled $\mathrm{K}$ (circled) suggesting two soils.

Pecica deposit and the subsequent Dacio-Roman occupation. Both field observation and the micromorphological examination of the Pecica deposit indicate significant bioturbation which could have mixed these sand-size artifacts into the matrix.

The results of the chemical analyses suggest significant similarities relative to a few minor differences between the Pecica deposit in Trench 1 and the upper soil profile revealed in Mureş 1. Perhaps the strongest evidence for a common origin for the Pecica deposit and the proposed Holocene loess at Mureş 1 is contained in Figure 6. Major element oxides including $\mathrm{Al}_{2} \mathrm{O}_{3}, \mathrm{CaO}, \mathrm{K}_{2} \mathrm{O}$, $\mathrm{Fe}_{2} \mathrm{O}_{3}, \mathrm{TiO}_{2}$, and $\mathrm{MgO}$ for the two materials are strikingly similar. However, when compared to the Mureş Paleosol in the Mureş 1 profile, significant differences are evident. $\mathrm{Al}_{2} \mathrm{O}_{3}$ and $\mathrm{CaO}$ values are significantly lower and the $\mathrm{MgO}$ value is significantly higher in the buried loess. The plots of $\mathrm{CaO} / \mathrm{TiO}_{2}$ with depth for the Trench 1 and Mureş 1 profiles show two distinct zones of low $\mathrm{Ca}$, the first from 0 to $48 \mathrm{~cm}$ (Ap horizons) and the second from 130 to $150+\mathrm{cm}$ (Figure 7). It is evident that carbonates have been partially leached from the epipedon 


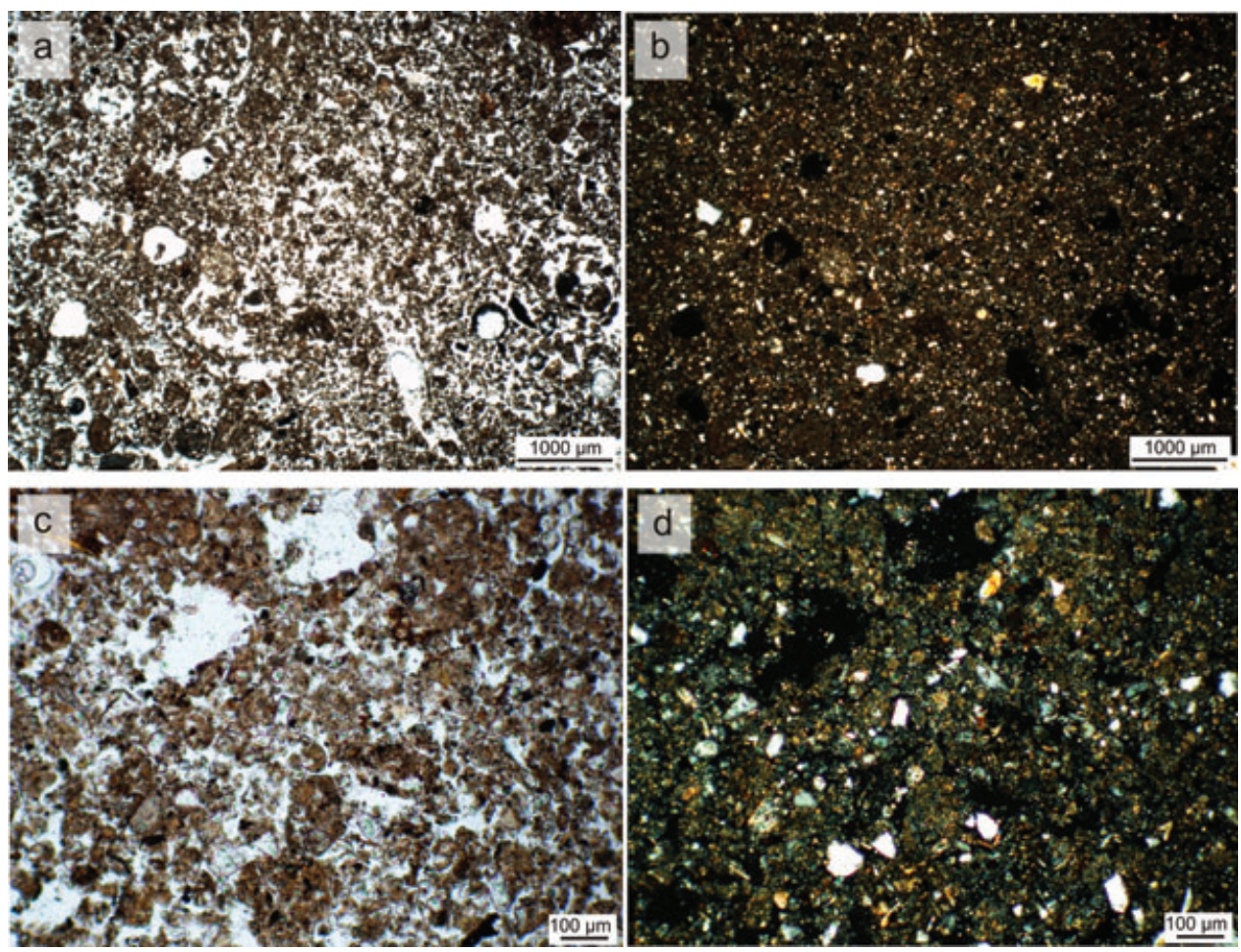

Figure 9 Photomicrographs of the Pecica deposit on top of the tell. (a) bioturbated microstructure of calcareous silt loam, plane-polarized light (PPL); (b) same view cross-polarized light (XPL); (c) increased magnification showing the predominant silt-size components with 5\% fine sand-size quartz and fragments of calcareous nodules, PPL; (d) same view in XPL. Sample 06PC114, Zone B2 (Layer 7 in Trench 1, north profile).

(surface horizon) resulting in the formation of subsurface horizons with $\mathrm{CaCO}_{3}$ filaments along peds and pore walls in the upper soil (Table I).

With regard to pedogenic processes, the Pecica deposit does not show any evidence for the translocation of clay either in the particle size analysis or in thin section, and in fact has a general decrease in clay content with depth (Table II). This lack is similar to Holocene loess deposits identified in Nebraska (Mason \& Kuzila, 2000). The translocation of clay is inhibited in calcic soils because calcium causes the clays to flocculate (Birkeland, 1999; Buol et al., 2003). Consequently, clay particles are unlikely to be translocated until leaching has removed most of the carbonates. The second leached zone from 130 to $150+\mathrm{cm}$ in Mureş 1 indicates that either the buried Mureş paleosol underwent a period of pedogensis prior to burial under a climatic regime with enough moisture to leach carbonates, or slow accumulation and syndepositional carbonate leaching took place. The lack of a significant clay increase below the decalcified horizon indicates that very little translocation of clay has occurred and that the clay content is related to the original parent material rather than pedogenic processes. Some loss of calcite appears to have occurred in the lower Bk2 horizon $(96-130 \mathrm{~cm})$ above the unconformity between the two soils, likely due to the acidifying effect of the leached surface of the underlying paleosol. The lower $\mathrm{pH}$ of the $2 \mathrm{Btkb}$ horizon commonly facilitates the loss of bases in the overlying calcareous loess (Schaetzel \& Anderson, 2005). Total element analysis of the Pecica deposit in Trench 1 indicates that its composition is distinctly different from the underlying and overlying deposits (Table III). Additionally, there are no observable trends with depth that would indicate chemical weathering and translocation of mobile elements through pedogenic processes. Graphs of $\mathrm{CaO}$ versus $\mathrm{Al}_{2} \mathrm{O}_{3}$ reveal that the Pecica deposit has not been significantly depleted of calcite and plots similarly to the $\mathrm{Bk}$ and $2 \mathrm{Bkb}$ horizons in the Mureş 1 profile (Figure 7).

The high levels of $\mathrm{P}_{2} \mathrm{O}_{5}$ in the Trench 1 strata likely reflect anthropogenic additions as they are significantly higher than the total P levels in the upper Mureş loess deposit (Table III). While anthropogenic enrichment of some elements is possible, major element concentrations are very similar between the Bk horizons in the Mureş 1 and the Trench 1 deposit suggesting these may be essentially the same deposit (Figure 6).

Efforts to secure radiocarbon dates from other Chernozems in central and Eastern Europe were unsuccessful. Apparently, no absolute age for their formation has been determined (dates measure mean residence time of 
organic carbon or the relative time of burning) but other evidence suggests at least some of these soils date to the middle-to-late Holocene. The formation of a Chernozem in a late Holocene loess deposit that dates shortly after the 16-17th century B.C. is thought to be possible, particularly if their formation is enhanced by anthropogenic additions of organic matter and field clearance, or management practices that include burning (common in the Mureş valley).

\section{Proxy Data Elsewhere in Central and Eastern Europe}

While the primary objective of this paper is to explore the likelihood of an aeolian origin for the Pecica deposit, we are also interested in the possibility for such a deposit to signal a period of aridification, potentially severely impacting the regional MBA. Aridification brought on by a warming trend is suggested in proxy forms elsewhere in Central and Eastern Europe. Along the northeastern Black Sea coast, pollen records reveal an expansion of steppe vegetation in the middle of the 17 th century B.C. (Bolikhovskaya et al., 2005). Across Eastern Europe, pollen records reveal accelerated replacement of deciduous trees by spruce and later birch and white alders, while charcoal counts reflect an increase in burning through the Subboreal (Gaigalas, 2005). In general, Gaigalas (2005) documents a precipitation decrease beginning during a warming trend around $3500 \mathrm{cal}$. yr B.P. By the onset of the Iron Age, 2600-2800 years ago, significant environmental degradation is documented with increasing soil erosion, aeolian deposition, and increasing river activity.

Isotopic data collected from a stalagmite in Ursilor Cave, NW Romania, suggest a warm dry period from 3500 to 2300 cal. yr B.P. (Onac et al., 2002). These dates correlate with those from fossil pollen assemblages from other parts of NW Romania that reveal a decrease in wetland plant taxa and increases in Carpinus (Hornebeam) and Fagus (Beech) at this time (Feurdean, 2001). These data also correspond with previously identified shortterm climatic oscillations, including a period of higher mean annual temperatures and warmer temperatures of the coldest months, coupled with erratic but generally reduced precipitation, beginning about 1650 B.C. (Feurdean et al., 2008). Speleothems in Poleva Cave, in the southern Carpathians (Locvei Mountains of Romania), less than $200 \mathrm{~km}$ south of Pecica, yielded detailed isotopic profiles into the Holocene (Constantin et al., 2001, 2007). These data indicate gradual warming with several notable events such as warming trends at $\sim 5.2$ and $\sim 3.3$ ka with rapid oscillations around a mean isotopic value of $-7.5 \%$.
The existence of mires or bogs, in conjunction with ${ }^{14} \mathrm{C}$ analysis, has also been used to produce detailed wet versus dry chronologies in Central Europe spanning the late Pleistocene and Holocene. Detailed paleohydrological conditions were determined using mire sediments from sites in the North Podlasie Lowland and the Southern piedmont of the Holy Cross Mountains of Poland. These results reveal highly decomposed peat layers representing a dry phase from 3400 to 3700 cal. yr B.P. (Zurek, Michczynska, \& Pazdur, 2002). These data, along with other wet and dry phases in the Holocene, are comparable to low water-level stands in Poland and French Jura lakes (Magny \& Ruffaldi, 1995; Zurek, Michczynska, \& Pazdur, 2002).

In a recent review using 80 different types of proxy data across the eastern Mediterranean and adjacent regions from the last 6000 years, Finné et al. (2011) take a detailed look at general temperature and humidity trends and limitations in the existing data. Southwestern Romania marks the northernmost point from which they integrate these data. Among the authors' conclusions is a "general consensus that the time period between 3400 and 2800 cal. yr was one of drier conditions and generally harsher conditions, although there is much inter-variability superimposed upon this general pattern..." (Finné et al., 2011:3167). Farfetched, but perhaps worth noting, is that the MBA abandonment proposed for Pecica-Şanţul Mare is generally contemporary with the volcanic event at Santorini/Thera. Radiocarbon dated to 1627-1600 B.C., this eruption, which resulted in significant weather change, has been correlated with important events in Aegean and east Mediterranean prehistory, specifically with the Bronze Age in that region (Friedrich et al., 2006). Climatic disturbances correlated with the volcanic ash from this event have been documented as far away as China, Ireland, and California (Baillie \& Munro, 1988; Friedrich et al., 2006).

\section{CONCLUSIONS}

Physical and chemical analyses of the homogeneous gray deposit atop the site of Pecica-Şanţul Mare indicates that it is composed of a calcareous silty clay loam-silt loam with characteristics similar to the Bk horizons in the Chernozems that blanket the surrounding area. Soil morphology coupled with the presence of a buried decalcified zone (Mureş Paleosol) in the Mureş 1 profile show that the overlying soil has likely developed in a separate loess deposit that has been welded to the truncated surface of the underlying paleosol. Such a deposit suggests both abrupt aridity and sediment availability (either on the Pleistocene terrace or on the floodplain below), 
consistent with regional deforestation and extensive cultivation of the calcareous soils. In the later stages at Pecica, the intensification of metal production and stock raising is clearly demonstrated (O'Shea et al., 2006, 2011; Nicodemus, 2011). These anthropogenic activities would have added to or amplified the effects of local climate change and drought.

The results of this study are not without a few caveats. While these data are compelling, the authors recognize that they are limited in extent. To be further tested, additional profiles should be analyzed (especially from neighboring sites). In addition, absolute age dates from the regional loess deposits in the general area are needed for a more comprehensive reconstruction of the Holocene geomorphology. This study should continue with efforts to trace the regional extent of these proposed Holocene loess deposits, both in archaeological and nonarchaeological contexts, while searching for additional proxies (e.g. suitable wetland deposits for pollen, pedogenic carbonate) to verify the nature of the landscape and refine the chronology and further test the validity of this potential climatic event.

Another avenue to consider is the blanket effect of loess deposition and the potential to cover fine-scale landscape variability including local anthropogenic modifications such as ditches, and the paucity or absence of sites from earlier time periods in regional surveys. Tells, as conspicuous mounds on the landscape, are only enhanced by such deposits, however less obvious cultural features and sites may be covered or obscured by such deposition. While systematic surveys are currently lacking in large parts of the Pannonian plain, our hope is that this hypothesis can be tested as regional survey databases are generated and expanded.

Finally, while rapid climate change cannot control cultural transformations, it can have a significant impact on the elements that make-up complex cultural systems. Expanding and refining these data have the potential to provide new insights into the region's Holocene climatic history and the dynamics of fluvial systems during the post-glacial period, while significantly expanding our synchronic view of the middle and late Bronze Age in the Eastern Carpathian Basin.

We are indebted to our Romanian colleagues, especially Drs. Florin Draşovean (Timişoara), Alexandru Szentmiklosi (Timişoara), Peter Huegel (Arad), Pascu Hurezan (Arad), and Dan Ciobotaru (Timişoara) for kindly receiving us and offering their expertise at Pecica-Şanţul Mare. The ICP results were produced in the Soil Chemistry Lab directed by Michael Essington of the Biosystems Engineering and Soil Science Department at the University of Tennessee. William Parkinson and Paul Goldberg provided valuable critiques of earlier drafts of this paper and three anonymous reviewers improved the clarity of the manuscript. Thank you to Paul Duffy who provided the base map for Figure 1. This research was funded by collaborative grants from the National Science Foundation (BCS 0512162 and BCS0620147, John O'Shea, University of Michigan; BCS 0512115 and BCS-0618307, Alex Barker, Milwaukee Public Museum and University of Missouri). We gratefully acknowledge this support.

\section{REFERENCES}

Andó, M. (1995). Geography of the River Maros (Mureş) and its river system. In J. Hamar \& A. Sárkány-Kiss (Eds.), The Maros/Mureş River Valley: A Study of the Geography, Hydrobiology and Ecology (pp. 7-23). Hungary: Tisza Klub (TISCIA Monograph Series).

Baillie, M.G.L., \& Munro, M.A.R. (1988). Irish tree rings, Santorini and volcanic dust veils. Nature, 332, 344-346.

Barczi, A., Toth, T.M., Csanadi, A., Sumegi, P., \& Czinkota, I. (2006). Reconstruction of the paleo-environment and soil evolution of the Csípo-halom kurgan, Hungary.

Quaternary International, 156/157, 49-59.

Birkeland, P.W. (1999). Soils and geomorphology. New York: Oxford University Press.

Bolikhovskaya, N., Kaitamba, M., Porotov, A., \& Fouache, E. (2005). Environmental changes of the northeastern Black Sea's coastal region during the middle and late Holocene. In E. Marian, A. Scott, A. Alekseev, \& G. Zaitseva (Eds.), Impact of the environment on human migration in Eurasia (pp. 209-223). The Netherlands: Springer.

Bogdanović, M. (1996). Mittelserbien in der Bronzezeit und die Vattina-Kultur. In N. Tasić (Ed.), The Yugoslav Danube basin and the neighboring regions in the 2 nd millennium B.C. (pp. 109-114). Serbian Academy of Science and Arts Institute for Balkin Studies, Special Editions No. 65 Belgrade.

Bullock, P., Fedoroff, N., Jongerius, A., Stoops, G., Tursina, T. \& Babel, U. (1985). Handbook for soil thin section descriptions. Waine research publications 152. Wolverhampton, U.K.: Albrighton.

Buol, S.W., Southard, R.J., Graham, R.C., \& McDaniel, P.A. (2003). Soil genesis and classification. Ames: Iowa State University Press.

Chengbang, A., Zhaudong, F., \& Tang, T. (2004). Environmental change and cultural response between 8000 and $4000 \mathrm{cal}$. yr BP in the western loess plateau, northwest China. Journal of Quaternary Science, 19, 529-535.

Clayton, L., Moran, S.R., \& Bickley, W.B. Jr. (1976). Stratigraphy, origin, and implications of Late Quaternary upland silt in North Dakota. North Dakota Geological Survey Miscellaneous Series, Vol. 54. North Dakota: Grand Forks.

Constantin, S., Onac, B.P., Fleitman, D., \& Tămaş, T. (2001). Past vegetation changes in karst areas as revealed by a comparative isotopic study of two Holocene speleothems from Romania. IGCP 448 Newsletter 2001, Karst Dynamics Lab. Guilin, China, pp. 67-73. 
Constantin, S., Bojar, A.V., Lauritzen, S.E., \& Lundberg, J. (2007). Holocene and late Pleistocene climate in the sub-Mediterranean continental environment: A speleothem record from Poleva cave (Southern Carpathians, Romania). Palaeogeography, Palaeoclimatology, Palaeoecology, 243, 322-338.

David, P.P. (1970). Discovery of Mazama ash in Saskatchewan, Canada. Canadian Journal of Earth Science, 7, 1579-1583.

Draşovean, F. (Ed.). (1999). Repertoriul arheologic al Mureşului Inferior: Judeţul Arad. Bibliotheca Historica et Archaeologica Banatica XXIV.

Driessen, P., Deckers, J., Spaargaren, O., \& Nachtergaele, F.O. (2001). Lecture notes on the major soils of the world. World Soil Resources Report, 94. Wageningen: FAO.

Eckmeier, E., Gerlach, R., Gehrt, E., \& Schmidt, M.W.I. (2007). Pedogenesis of Chernozems in central Europe-a review. Geoderma, 139, 288-299.

Feurdean, A. (2001). Holocene forest dynamics in northwestern Romania. The Holocene, 15, 435-446.

Feurdean, A., Klotz, S., Mosbrugger, V., \& Wohlfarth, B. (2008). Pollen-based quantitative reconstructions of Holocene climate variability in NW Romania. Palaeogeography, Palaeoclimatology, Palaeoecology, 260(3-4), 494-504.

Finke, P.A., \& Hutson, J.L. (2008). Modeling soil genesis in calcareous loess. Geoderma, 145, 462-479.

Finné, M., Holmgren, K., Sundqvist, H.S., Weiberg, E., \& Lindblom, M. (2011). Climate in the eastern Mediterranean, and adjacent regions, during the past 6000 years: A review. Journal of Archaeological Science, 38, 3153-3173.

Fitzsimmons, K.E., Marković, S.B., \& Hambach, U. (2012). Pleistocene environmental dynamics recorded in the loess of the middle and lower Danube basin. Quaternary Science Reviews, 41:104-118.

Florea, N., Ghitulesch, N., Mihnea, I., \& Munteanu, I. (1978). Harta Solurilor, Republica Socialistá Romània. Soil Pedo-Geographia Map of Romania, Institutul de Cercetări pentru Pedologie şi Agrochimie 1:500,000. Inst. Geol. Bucuresti.

Friedrich, W.L., Kromer, B., Friedrich, M., Heinemeier, J., Pfeiffer, T., \& Talamo, S. (2006). Santorini eruption radiocarbon dated to $1627-1600 \mathrm{BC}$. Science, 312 , 548.

Gaigalas, A. (2005). Environmental study of the Bronze-Iron Age transition period of Eastern Europe. In E. Marian Scott, A. Alekseev, \& G. Zaitseva (Eds.), Impact of the environment on human migration in Eurasia (pp. 243-254). The Netherlands: Springer.

Gogâltan, F. (2008). Fortified Bronze Age tell settlements in the Carpathian Basin: A general overview. In J. Czebreszuk, S. Kadrow, \& J. Müller (Eds.), Defensive structures from Central Europe to the Aegean in the 3rd and 2nd millennia BC (pp. 39-56), Studien zur
Archäologie in Ostmitteleuropa 5, Poznań: Wydawnictwo Poznańskie; Bonn: Habelt.

Gumä, M. (1997). The Bronze Age in Banat: Chronological levels and cultural entities. Timisoara: Mirton.

Gyucha, A., Duffy, P.R., \& Frolking, T.A. (2011). The Körös Basin from the Neolithic to the Hapsburgs: Linking settlement distributions with pre-regulation hydrology through multiple data set overlay. Geoarchaeology: An International Journal, 26, 392-419.

Harding, A., (2000). European societies in the Bronze Age. Cambridge: Cambridge University Press.

Hasse, D., Fink, J., Hasse, G., Ruske, R., Pécsi, M., Richter, H., Altermann, M., \& Jäger K.-D. (2007). Loess in Europe-Its spatial distribution based on a European Loess Map, scale 1:2,500,000. Quaternary Science Reviews, 26, 1301-1312.

Jacobs, P.M., \& Mason, J.A. (2004). Paleopedology of soil in thick Holocene loess, Nebraska, USA. Revista Mexcicana de Ciencias Geologicas, 21, 54-70.

Jobbagy, E.G., \& Jackson, R.B. (2001). The distribution of soil nutrients with depth: Global patterns and the imprint of plants. Biogeochemistry, 53, 51-77.

Kirby, E.F. (1985). A basis for soil profile modeling in a geomorphic context. Journal of Soil Science, 36, 97-121.

Kiss, T., Oroszi, V.G., S. György, Károly, F., \& Benyhe, B. (2011). Accelerated overbank accumulation after nineteenth century river regulation works: A case study on the Maros River, Hungary. Geomorphology 135, 191-202.

Lengyel, S. (2010). Archaeomagnetic laboratory results for three samples from Pecica-Şanţul Mare, Romania. Illinois State Museum Landscape History Program Technical Report 2010-000-6.

Lewis, R.J., Foss, J.E., Morris, M.W., Timpson, M.E., \& Stiles, C.A. (1993). Trace element analysis in pedo-archaeology studies. In J.M. Foss, M.E. Timpson, \& M.W. Morris (Eds.), Proceedings of the First International Conference on Pedo-Archaeology (pp. 81-88). University of Tennessee-Knoxville Special Publication.

Magny, M., \& Ruffaldi, P. (1995). Younger Dryas and Early Holocene lake-level fluctuations in the Jura Mountains, France. Boreas, 24, 155-172.

Markewich, H.W., Wysocki, D.A., Pavich, M.J., Rutledge, E.M., Millard, H.T. Jr., Rich, F.J., Maat, P.B., Rubin, M., \& McGeehin, J.P. (1998). Paleopedology plus TL, ${ }^{10} \mathrm{Be}$, and ${ }^{14} \mathrm{C}$ dating as tools in stratigraphic and paleoclimatic investigations, Mississippi River Valley, U.S.A. Quaternary International, 51/52, 143-167.

Marković, S.B., Hambach, U., Stevens, T., Kukla, G.J., Heller, F., McCoy, W.D., Oches, E.A., Buggle, G., \& Zöller, L. (2011). The last million years recorded at the Stari Slankamen (Northern Serbia) loess-palaeosol sequence: Revised chronostratigraphy and long-term environmental trends. Quaternary Science Reviews, 30, 1142-1154.

Mason, J.A., \& Kuzila, M.S., (2000). Episodic Holocene loess deposition in central Nebraska. Quaternary International, 67, 119-131. 
Muhs, D.R., \& Bettis, E.A., III. (2000). Geochemical variations in Peoria loess of western Iowa indicate paleowinds of midcontinental North America during Last Glaciation. Quaternary Research, 53, 49-61.

Muhs, D.R., Bettis, E.A., III, Been, J., \& McGeehin, J.P. (2001). Impact of climate and parent material on chemical weathering in loess-derived soils of the Mississippi River Valley. Soil Science Society of America Journal, 65, 1761-1777.

Nádor, A., Ehamó-Bozsó, E., Magyari, Á., \& Babinszki, E. (2007). Fluvial responses to tectonics and climate change during the Late Weichselian in the eastern part of the Pannonian Basin (Hungary). Sedimentary Geology, 202, 174-192.

Nicodemus, A. (2011). The Bronze Age and Dacian fauna from new excavations at Pecica "Şanţul Mare" Analele Banatului Series Noua Arheologie-Istorie XIX (2011) Muzeul Banatului Timisoara.

Onac, B. P., Constantin, S., Lundberg, J., \& Lauritzen, S. (2002). Isotopic climate record in a Holocene stalagmite from Ursilor Cave (Romania). Journal of Quaternary Science, 17, 319-327.

O'Shea, J.M. (1992). A radiocarbon-based chronology for the Maros-Group of southeast Hungary. Antiquity, 60, 97-102.

O'Shea, J.M. (1996). Villagers of the Maros: A portrait of an Early Bronze Age society. New York: Plenum Press.

O'Shea, J.M., Barker, A.W., Sherwood, S., \& Szentmiklosi, A. (2005). New excavations at Pecica-“Şanţul Mare". Analele Banatului Series Noua Arheologie-Istorie XII-XIII (2004-2005), Muzeul Banatului Timisoara.

O'Shea, J.M., Barker, A.W., Nicodemus, A., Sherwood, S., \& Szentmiklosi, A. (2006). Archaeological investigations at Pecica-"Şanţul Mare," The 2006 campaign. Analele Banatului Series Noua Arheologie-Istorie XIV (2006), Muzeul Banatului Timisoara.

O'Shea, J.M., Barker, A.W., Motta, L., \& Szentmiklosi, A. (2011). Archaeological investigations at Pecica-“Şanţul Mare 2006-2009. Analele Banatului Series Noua Arheologie-Istorie XIX (2011), Muzeul Banatului Timisoara.

Pécsi, M. (1990). Loess is not just the accumulation of dust. Quaternary International, 7-8, 1-21.

Pîrv, O., \& Pascu, M. (2006). Ramser Wetland - Mureş Floodplain Natural Park, Arad 310084. Episcopiei no. 48, County Arad, Romania. http://www.wetlands.org/reports/ ris/3RO004_RISen06.pdf.

Porder, S., \& Chadwick, O.A. (2009). Climate and soil-age constraints on nutrient uplift and retention by plants. Ecology, 90, 623-636.

Pye, K. (1995). The nature, origin and accumulation of loess. Quaternary Science Reviews, 14, 653-667.

Pye, K., \& Johnson, R. (1988). Stratigraphy, geochemistry, and thermoluminescence ages of Lower Mississippi Valley loess. Earth Surface Processes and Landforms, 13, 103124.

Rost, K.T. (2001). Late Holocene loess deposits and dust accumulation in the alpine meadow belt of the Wutai Shan, China. Quaternary International, 76/77, 85-92.

Ruhe, R.V. (1984). Loess-derived soils, Mississippi Valley region: I. Soil-sediment system. Soil Science Society of America Journal, 48, 859-863.

Sandu, I. (2011) Revista Ştiingţificá: a Administratiei Nationale de Meterorologie. Publicat de Administra ia na Ional de Meteorologie.

Schaetzel, R., \& Anderson, S. (2005). Soils, genesis and geomorphology. Cambridge: Cambridge University Press.

Schoeneberger, P.J., Wysocki, D.A., Benham, E.C., \& Broderson, W.D. (Eds.). (2002). Field book for describing and sampling soils, Version 2.0. Lincoln, NE: Natural Resource Conservation Service, National Soil Survey Center.

Smalley, I. (1995). Making the material: The formation of silt sized primary mineral particles for loess deposits. Quaternary Science Reviews, 14, 645-651.

Soil Survey Laboratory Staff. (2004). Soil laboratory methods manual. Soil Survey Investigations Report No. 42, United States Department of Agriculture, Natural Resource Conservation Service. U.S. Washington, D.C.: Government Printing Office.

Stoops, G. (2003). Guidelines for analysis and description of soil and regolith thin sections. Madison, WI: Soil Science Society of America, Inc.

Tasić, N. (1984). Die Vatin-Kultur. In N. Tasić (Ed.), Kulturen der Frühbronzezeit das Karpatenbeckens und Nordbalkans (pp. 60-82). Beograd: Balkanološki Institut Sanu.

Vreeken, W.J. (1994). A Holocene soil-geomorphic record from the Hamsite near Frontier, southwestern Saskatchewan. Canadian Journal of Earth Science, 31, 532-543.

Zurek, S., Michczynska, D.J., \& Pazdur, A. (2002). Time record of palaeohydrologic changes in the development of Mires during the late glacial and Holocene, North Podlasie Lowland and Holy Cross Mountains. Geochronometria, 21 , 109-118. 